\title{
IMPLEMENTASI KONSEP RUMAH ISLAMI PADA PERUMAHAN DI MARTAPURA
}

\author{
Nurul Hidayati ${ }^{1}$ \\ ${ }^{1}$ Dinas Pekerjaan Umum Dan Penataan Ruang Kabupaten Banjar
}

\begin{abstract}
ABSTRAK
Beberapa tahun terakhir, pembangunan rumah sederhana (tipe $36 \mathrm{~m}^{2}$ dan $45 \mathrm{~m}^{2}$ ) yang dikembangkan oleh developer semakin marak dilakukan. Tidak terkecuali di kota Martapura yang dikenal juga dengan julukan Kota Serambi Mekah. Karena kota Martapura adalah kota yang religius, maka secara tidak langsung berimbas pada pola perilaku masyarakatnya yang bergaya hidup Islami dan berkebudayaan Islami, seperti: cara berpakaian yang lebih tertutup, berperilaku baik dalam hubungan sosial dan di tempat umum. Bahkan sebagian besar acara-acara yang diselenggarakan bersumber dari budaya Islami dan bertemakan Islami. Namun, apakah penataan ruang rumah sederhana di komplek perumahan di Martapura sudah berkonsep Islami?

Tujuan penelitian adalah menganalisis seberapa besar pengetahuan masyarakat Martapura tentang konsep rumah Islami, membuat contoh denah rumah yang berkonsep Islam dan menghitung biaya pembangunan rumah sederhana yang berkonsep Islami. Untuk itu, penelitian ini dilakukan dengan mengadakan survei menggunakan instrumen berupa kuisioner sebagai data primer. Dengan mengukur pengetahuan masyarakat tentang konsep rumah Islami, karakteristik rumah responden (penataan ruang), dan rencana renovasi rumah eksisting menjadi rumah berkonsep Islami. Sampel penelitian berjumlah 300 orang. Teknik analisis data menggunakan analisis deskriptif.

Hasil penelitian menunjukkan bahwa pengetahuan masyarakat Martapura tentang konsep dasar sebuah rumah Islami dan ciri-ciri rumah Islami masih kurang diketahui dan dipahami. Begitu pula dengan penataan ruang rumah pada perumahan di Martapura masih ada sebagian yang kurang sesuai dengan konsep rumah Islami. Padahal tata ruang rumah berkonsep Islami tidak terlalu jauh berbeda dengan rumah yang biasa dibangun oleh developer. Dan selisih biaya pembangunannya pun tidak terlalu besar. Untuk rumah sederhana tipe 36 dengan luas tanah $100 \mathrm{~m}^{2}-120 \mathrm{~m}^{2}$ selisih biayanya hanya sekitar Rp. 1,3 juta - Rp. 1,5 juta. Sedangkan untuk rumah sederhana tipe 45 dengan luas tanah 140m2 selisih biayanya hanya sekitar Rp. 1,8 juta.
\end{abstract}

Kata kunci: rumah Islami, perumahan, rumah sederhana, penataan ruang, biaya.

\section{PENDAHULUAN}

Sebagai makhluk sosial, manusia harus berinteraksi/berhubungan dalam kehidupan sehari-harinya. Tidak hanya untuk melengkapi kebutuhan hidup, tapi juga sebagai tambahan wawasan/pengetahuan dan hiburan. Bahkan dalam ajaran agama Islam, hubungan tersebut dibagi menjadi 2 (dua), yaitu hubungan dengan Allah (hablum minallah) dan hubungan dengan sesama manusia (hablum minannas). Salah satu wujud nyata dari hablum minannas adalah

Correspondence: Nurul Hidayati

Email: nurulnabhan@gmail.com saling mengunjungi teman, kerabat, keluarga, kolega/partner kerja ataupun menghadiri undangan.

Seringkali kita mengalami kekurang nyamanan saat berkunjung ke rumah teman, kerabat, keluarga, kolega/partner kerja, khususnya bagi mereka yang kita kunjungi menempati rumah sederhana (tipe $36 \mathrm{~m}^{2}$ dan $45 \mathrm{~m}^{2}$ ) di komplek perumahan yang dibangun oleh pengembang (developer). Seperti adanya anggota rumah yang tidak menutup aurat \& terlihat tamu. Atau pada saat kita berbicara serius dengan tuan rumah namun terganggu oleh suara televisi atau tangisan bayi di sampingnya. Bahkan saat kita meminjam kamar kecil, kita harus melihat isi rumah yang 
sebenarnya itu privasi penghuni rumah. Penataan ruang rumah sangat mempengaruhi keadaan demikian, dimana ruang tamu menyatu dengan ruang keluarga. Juga pintu kamar tidur yang menghadap ke ruang tamu. Ataupun posisi pintu masuk yang menghadap langsung ke ruang keluarga. Ironisnya, penataan ruang rumah demikian sudah umum dipakai oleh sebagian besar developer yang membangun perumahan.

Beberapa tahun terakhir, pembangunan rumah sederhana yang dikembangkan oleh developer semakin marak dilakukan. Hal ini dikarenakan kebutuhan akan tempat tinggal semakin tinggi, dan daya beli masyarakat juga tinggi. Keadaan ini berbanding lurus dengan program pemerintah pusat untuk menyediakan 1 (satu) juta unit rumah dalam rangka mengurangi backlog. Tidak terkecuali di kabupaten Banjar khususnya kota Martapura.

Kota Martapura sebagai ibukota Kabupaten Banjar di Propinsi Kalimantan Selatan dikenal juga dengan julukan Kota Serambi Mekah. Adanya pondok pesantren terkenal seperti Pondok Pesantren Darussalam dan Darul Hijrah, dan ulama kharismatik terkenal seperti K.H Zaini Abdul Ghani, membuat Kota Martapura dikenal dengan kota yang religius. Hal ini secara tidak langsung berimbas pada pola perilaku masyarakatnya yang bergaya hidup Islami dan berkebudayaan Islami, seperti: cara berpakaian yang lebih tertutup, berperilaku baik dalam hubungan sosial dan di tempat umum. Dan sebagian besar acara-acara yang diselenggarakan bersumber dari budaya Islami dan bertemakan Islami.

Dukungan dari Pemerintah Daerah terhadap pola perilaku seperti ini semakin nonjolkan identitas Kota Martapura sebagai Kota yang Islami. Seperti dengan membuat Surat Edaran Bupati Banjar No. 065.2/00023/ORG Tertanggal 12 Januari 2004 Tentang pemakaian Jilbab bagi PNS Perempuan di Lingkungan Pemerintah Kabupaten Banjar, menerbitkan Peraturan Daerah Nomor 4 Tahun 2004 tentang Khatam Al-Qur'an Bagi Peserta Didik pada Pendidikan Dasar dan Menengah di Kabupaten Banjar, Peraturan Daerah Nomor 5 Tahun 2004 tentang Ramadhan, Peraturan
Daerah Nomor 8 Tahun 2005 tentang Jum'at Khusyu di Kabupaten Banjar, serta Peraturan Daerah Nomor 5 Tahun 2006 tentang Penulisan Identitas dengan Huruf Arab Melayu di Kabupaten Banjar. Namun yang paling mendasari pola perilaku hidup Islami adalah dimulai dari diri muslim itu sendiri. Pendidikan agama sejak dini dan pengaruh lingkungan sekitar sangat mendominasi dalam membentuk pola perilaku seseorang. Hal ini dimulai dari rumah tinggal dan lingkungan sekitar tempat tinggalnya.

Seperti yang dikemukakan oleh Rapoport (1969: 61) bahwa bentuk rumah tinggal dipengaruhi oleh aspek-aspek yang berkaitan dengan cara melakukan aktivitas dasar, struktur keluarga, peran gender, privasi, dan proses sosial. Dalam membangun rumah tinggal, selain faktor dana dan ukuran lahan, aktivitas, hobby, kebutuhan dasar dan jumlah penghuni menentukan desain dan jumlah ruang rumah tinggal. Bagi yang mempunyai dana cukup, akan membangun sendiri rumah tinggal sesuai kebutuhannya. Namun bagi yang dananya terbatas, solusi terbaik adalah dengan membeli rumah di komplek perumahan yang dibangun oleh pengembang/developer. Akan tetapi, apakah penataan ruang rumah di komplek perumahan di Martapura sudah berkonsep Islami?

\section{METODE PENELITIAN}

Penelitian ini berusaha menggambarkan tentang penataan ruang rumah sederhana (tipe $36 \mathrm{~m}^{2}$ dan $45 \mathrm{~m}^{2}$ ) di komplek perumahan di Martapura yang dibangun oleh pengembang/developer dan membandingkannya dengan konsep rumah Islami. Penelitian ini dilakukan dengan mengadakan survei menggunakan instrumen berupa kuisioner dan wawancara sebagai data pokok. Penelitian memberikan gambaran pengetahuan masyarakat Martapura tentang konsep rumah Islami, denah rumah dengan konsep Islami, biaya yang diperlukan untuk membangun rumah tipe 36 atau 45 dengan konsep Islami serta biaya renovasi rumah tipe 36 agar menjadi rumah dengan konsep Islami.

Teknik pengumpulan data dari penelitian ini adalah mengumpulkan hasil kuisioner sebanyak 300 sampel (data primer) dan meminta data perumahan pada dinas 
terkait (data sekunder). Teknik pengambilan sampling dilakukan dengan cara teknik cluster sampling, kemudian teknik proportionate stratified random sampling dan selanjutnya teknik simple random sampling.

Dalam kuisioner diberikan pertanyaan dan pernyataan dengan variabel karakteristik penghuni, pengetahuan responden tentang konsep rumah Islami, karakteristik rumah responden, dan rencana renovasi. Pengukuran dilakukan dengan skala Likert, Guttman,dan nominal. Analisis data dilakukan dengan uji validitas, reliabilitas, dan analisis deskriptif. Adapun lokasi pengambilan dan jumlah sampel dapat dilihat pada Tabel 1

Tabel 1. Lokasi Pengambilan dan Jumlah Sampel

\begin{tabular}{|c|c|c|c|c|}
\hline \multirow{2}{*}{ No } & \multirow{2}{*}{ Wilayah } & \multirow{2}{*}{ Lokasi Perumahan } & \multicolumn{2}{|c|}{ Jumlah Sampel } \\
\hline & & & tipe 36 & tipe 45 \\
\hline \multirow[t]{2}{*}{1} & Kelurahan Sekumpul & Perumahan Ibnu Sina & 0 & 7 \\
\hline & & Perumahan Graha Tegar Madani & 13 & 13 \\
\hline \multirow[t]{5}{*}{2} & Desa Bincau & Perumahan Griya Anggrek Merah IV & 17 & 0 \\
\hline & & Perumahan Kebun Serai Permai I & 17 & 6 \\
\hline & & Perumahan Mitra Jaya Permai & 0 & 9 \\
\hline & & Perumahan Permata Bincau & 17 & 0 \\
\hline & & Perumahan Mahkota Ridilla & 17 & 0 \\
\hline \multirow[t]{3}{*}{3} & Desa Indrasari & Perumahan Antero Permai Indrasari & 0 & 13 \\
\hline & & Perumahan Indrasari Indah Jaya & 7 & 0 \\
\hline & & Perumahan Candra Kirana Permai 1 & 20 & 0 \\
\hline \multirow[t]{4}{*}{4} & Desa Sungai Sipai & Perumahan Mustika Griya Permai & 29 & 13 \\
\hline & & Perumahan Sungai Sipai Permai & 9 & 0 \\
\hline & & Perumahan Aulia Permai & 20 & 0 \\
\hline & & Perumahan Banjar Mas & 9 & 13 \\
\hline \multirow[t]{2}{*}{5} & Desa Tungkaran & Perumahan Griya Sungkar Perdana & 20 & 0 \\
\hline & & $\begin{array}{l}\text { Perumahan Bukit Lambung } \\
\text { Mangkurat Raya }\end{array}$ & 23 & 0 \\
\hline
\end{tabular}

\section{HASIL DAN PEMBAHASAN}

\subsection{Pengetahuan Masyarakat Martapura tentang Konsep Rumah Islami}

Hasil penelitian pengetahuan masyarakat Martapura menunjukkan bahwa mereka memahami tentang konsep rumah Islami. Walaupun 37,3\% mengatakan cukup paham, dan 26,7\% mengatakan bahwa mereka paham akan konsep rumah Islami. Bahkan mereka berkeinginan untuk memiliki rumah dengan konsep Islami. Namun saat ditanyakan ciri-ciri rumah Islami, hanya $31,7 \%$ yang menyatakan mengetahuinya. Setelah disampaikan ciri-ciri rumah Islami dan responden diminta untuk memilih 5 hal yang mereka anggap penting, ternyata mayoritas responden menjatuhkan pilihan pertama pada meminimalkan hiasan berupa patung atau gambar manusia atau binatang. Ini menunjukkan bahwa pengetahuan masyarakat Martapura tentang konsep rumah Islami masih kurang.

Saat dilakukan wawancara diketahui, ciri-ciri rumah Islami yang diketahui sebagian besar responden adalah yang biasa berlaku di masyarakat saja. Seperti tidak boleh ada hiasan berupa patung, boneka besar, gambar manusia atau binatang di dalam rumah. Tidak ada pernak pernik yang menyerupai simbol agama selain Islam, tidak memelihara anjing \& babi, memiliki musholla di dalam rumah, memiliki pajangan kaligrafi atau ulama-ulama besar, arah saat buang hajat (posisi kloset) 
yang tidak menghadap kiblat, \& penghuninya melaksanakan syariat Islam. Serta kamar anak laki-laki dan perempuan harus dipisah. Sedangkan konsep dasar dari rumah Islami itu sendiri, yaitu tata ruang rumah yang menjaga privasi penghuninya, hanya sebagian kecil responden yang mengetahuinya.

\subsection{Penataan Ruang}

Hasil penelitian menunjukkan bahwa tata ruang rumah pada perumahan yang dibuat developer masih ada beberapa yang kurang sesuai dengan ciri-ciri rumah berkonsep Islami. Hal ini disebabkan beberapa faktor, diantaranya: 1) karena luas rumah tidak mencukupi untuk memenuhi semua kriteria rumah Islami; 2) karena kekurang pahaman developer tentang rumah dengan konsep Islami; 3) karena developer ingin menekan biaya pembangunan; 4) memudahkan saat acara hajatan yang sering dilakukan masyarakat; 5) karena kekurang pedulian developer akan rumah dengan konsep Islami di Martapura dan ciri khas kota Martapura yang religius. Atau karena sudah terbiasa/ikut- ikutan denah rumah yang sering dibangun oleh developer lainnya. Walaupun demikian, tidak sedikit penghuni rumah yang menata kembali ruang dalam/luar rumah untuk kenyamanan dan privasi mereka. Baik itu melakukan penambahan bangunan (renovasi) maupun hanya sekedar penambahan dinding semi permanen atau membeli barang yang dapat dijadikan sekat.

\subsection{Denah rumah sederhana berkonsep Islami}

Berdasarkan tujuan dari penelitian ini, maka dari hasil wawancara dan kuesioner, dibuatkanlah denah rumah sederhana yang berkonsep Islami. Terdapat beberapa alternatif yang diperoleh yaitu rumah tipe 36/120 berkonsep Islami dengan posisi $\mathrm{WC} /$ kamar mandi di dalam, rumah tipe 36/120 berkonsep Islami dengan posisi $\mathrm{WC} / \mathrm{kamar}$ mandi di luar dan rumah tipe 45/120-160 berkonsep Islami. Adapun masing-masing alternatif denah dapat dilihat pada Gambar 1 sampai dengan 3 berikut.

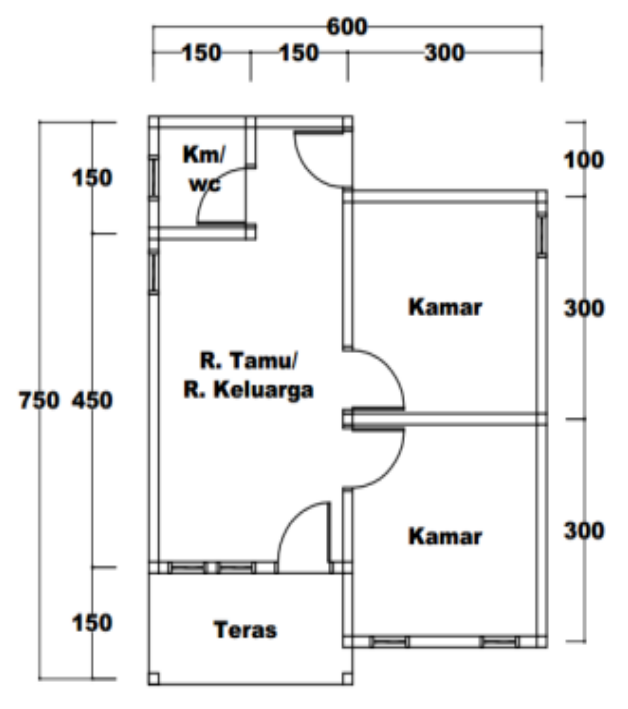

Denah Type 36

Yang Umum Dipakai
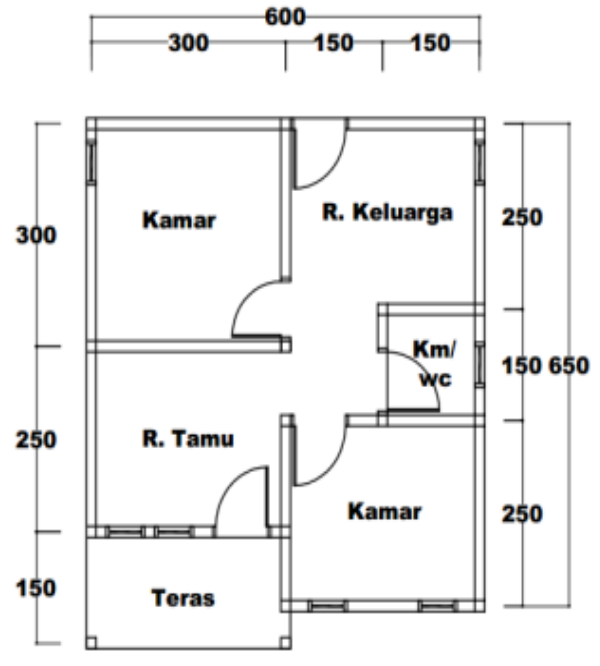

Denah Type 36

Konsep Islami

Gambar 1. Perbandingan Denah Rumah Tipe 36/120 Umum \& Konsep Islami Posisi WC/Kamar Mandi di Dalam 


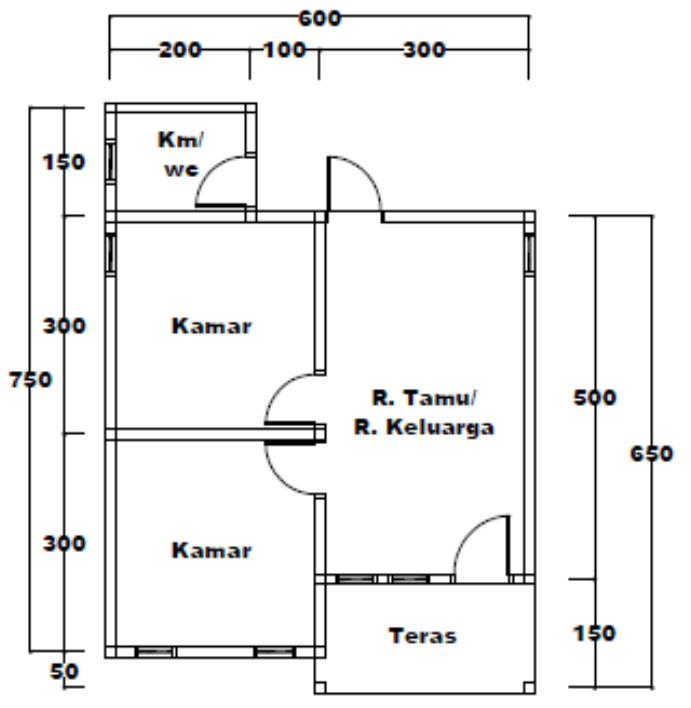

Denah Type 36 Yang Umum Dipakai
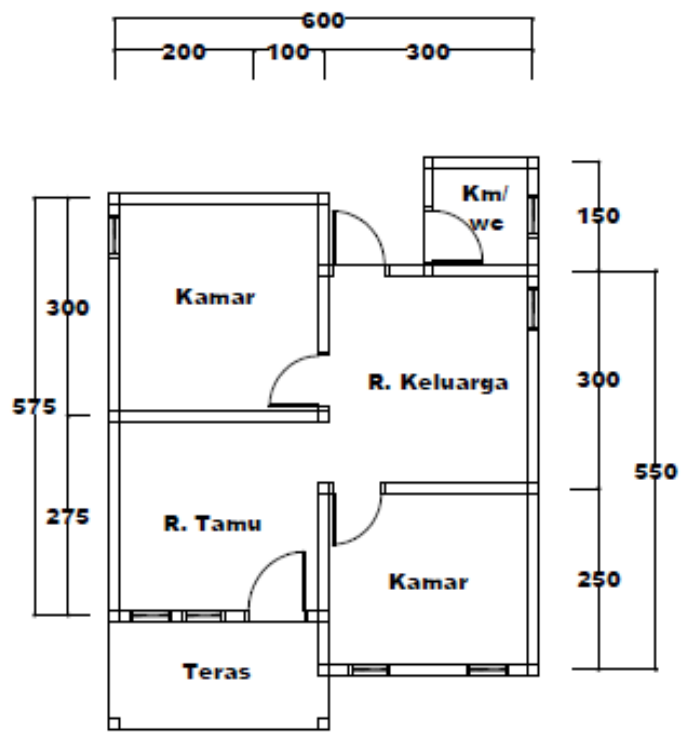

Denah Type 36 Konsep Islami

Gambar 2. Perbandingan Denah Rumah Tipe 36/120 Umum \& Konsep Islami Posisi WC/Kamar Mandi di Luar

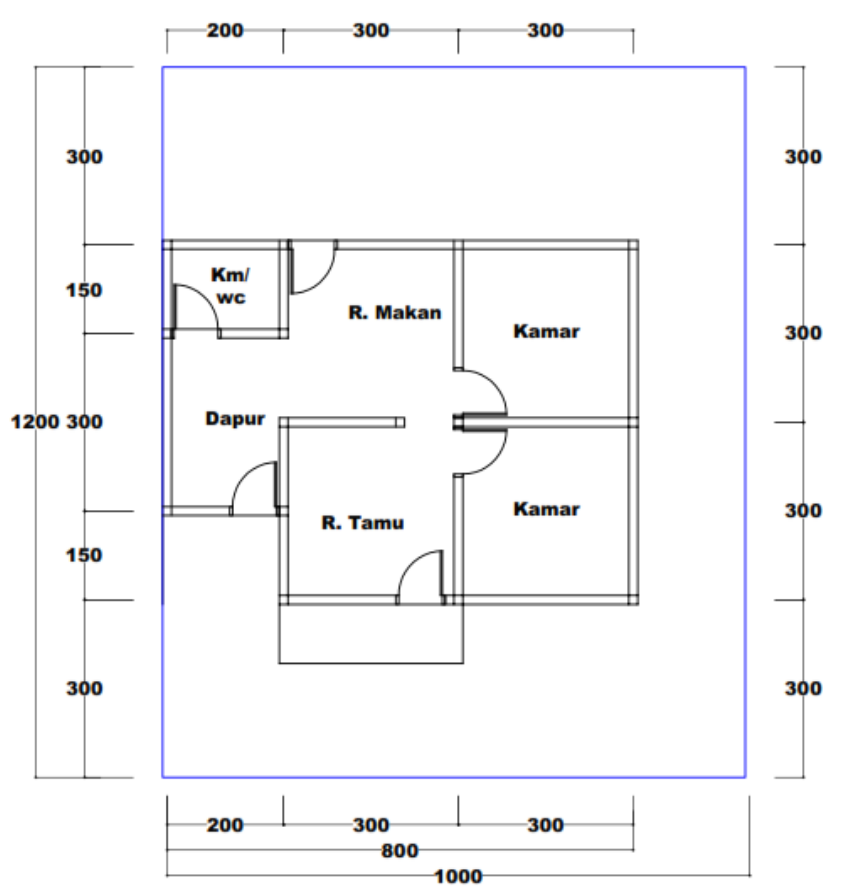

Denah Type 45 Yang Umum Dipakai

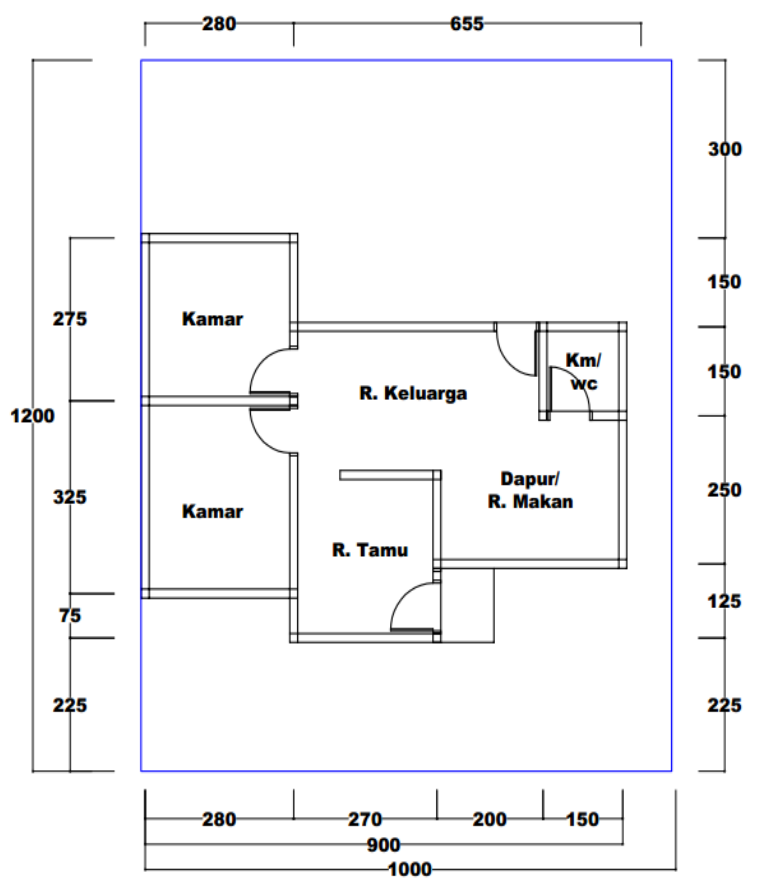

Denah Type 45

Konsep Islami

Gambar 3. Perbandingan Denah Rumah Tipe 45/120-160 Umum \& Konsep Islami 


\subsection{Biaya Pembangunan Rumah Sederhana Berkonsep Islami}

Setelah dilakukan perhitungan biaya dengan harga satuan yang digunakan adalah harga satuan hasil survei pasar di Kecamatan Martapura tahun 2017 akhir. Dan analisa pekerjaan yang digunakan adalah berdasarkan SNI 2008. Maka didapat hasil perhitungan dan selisihnya.

Untuk rumah sederhana tipe 36/120 dengan posisi $\mathrm{WC} / \mathrm{KM}$ di dalam didapatkan bahwa untuk rumah Umum diperlukan biaya pembangunan sebesar Rp. 108.594.000, sedangkan dengan konsep Islami sebesar Rp. 109.906.000. Sehingga terdapat selisih sebesar Rp. 1.312.000.

Adapun untuk rumah sederhana tipe 36/120 dengan posisi WC/KM di luar didapatkan bahwa untuk rumah Umum diperlukan biaya pembangunan sebesar Rp. 108.942.000, sedangkan dengan konsep Islami sebesar Rp. 110.388.000. Sehingga terdapat selisih sebesar Rp. 1.446.000.

Sedangkan untuk rumah sederhana tipe 45/120-160 didapatkan bahwa untuk rumah Umum diperlukan biaya pembangunan

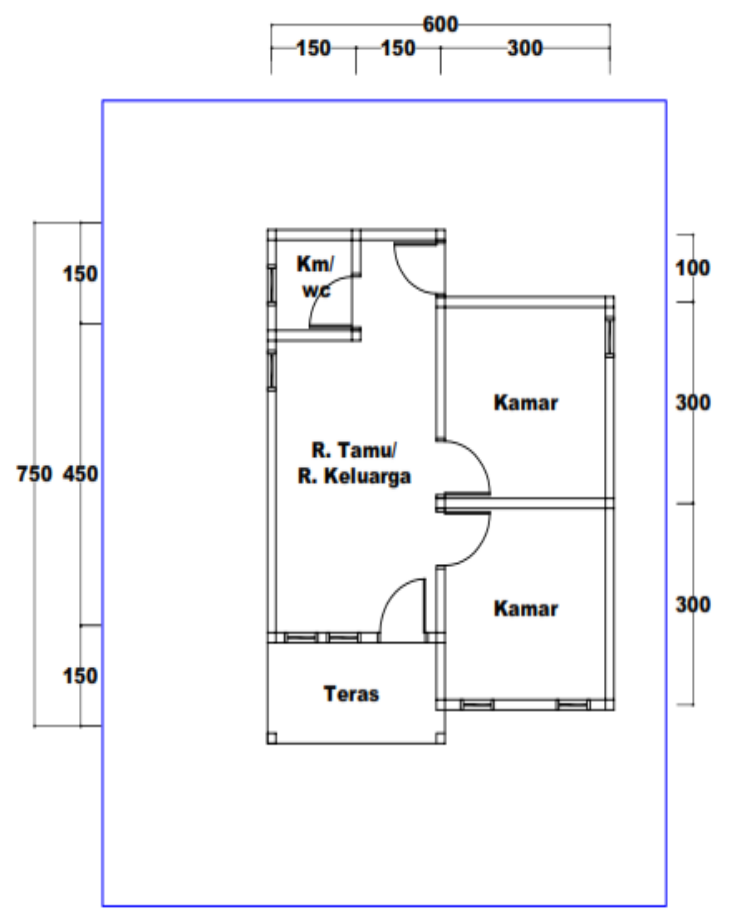

(a) sebesar Rp. 139.454.000, sedangkan dengan konsep Islami sebesar Rp. 137.707.000. Sehingga terdapat selisih sebesar Rp. 1.747.000.

Secara umum, dapat dikatakan bahwa untuk pembangunan rumah dengan konsep Islami untuk tipe 36 memang lebih mahal dibandingkan dengan biaya pembangunan rumah untuk tipe 36 pada umumnya. Akan tetapi perbedaan biaya tersebut tidak signifikan. Bahkan, untuk tipe 45, biaya pembangunan rumah dengan konsep Islami lebih murah dibandingkan dengan biaya pembangunan rumah untuk tipe 45 pada umumnya

\subsection{Biaya Renovasi Rumah Sederhana menjadi Rumah Konsep Islami}

Adapun biaya renovasi rumah seperti yang ditunjukkan pada Gambar 4 adalah sebesar Rp. 30.377.000,- (tiga puluh juta tiga ratus tujuh puluh tujuh ribu rupiah). Sedangkan biaya renovasi rumah seperti yang ditunjukkan pada Gambar 5 adalah sebesar Rp. 31.292.000,- (tiga puluh satu juta dua ratus sembilan puluh dua ribu rupiah).

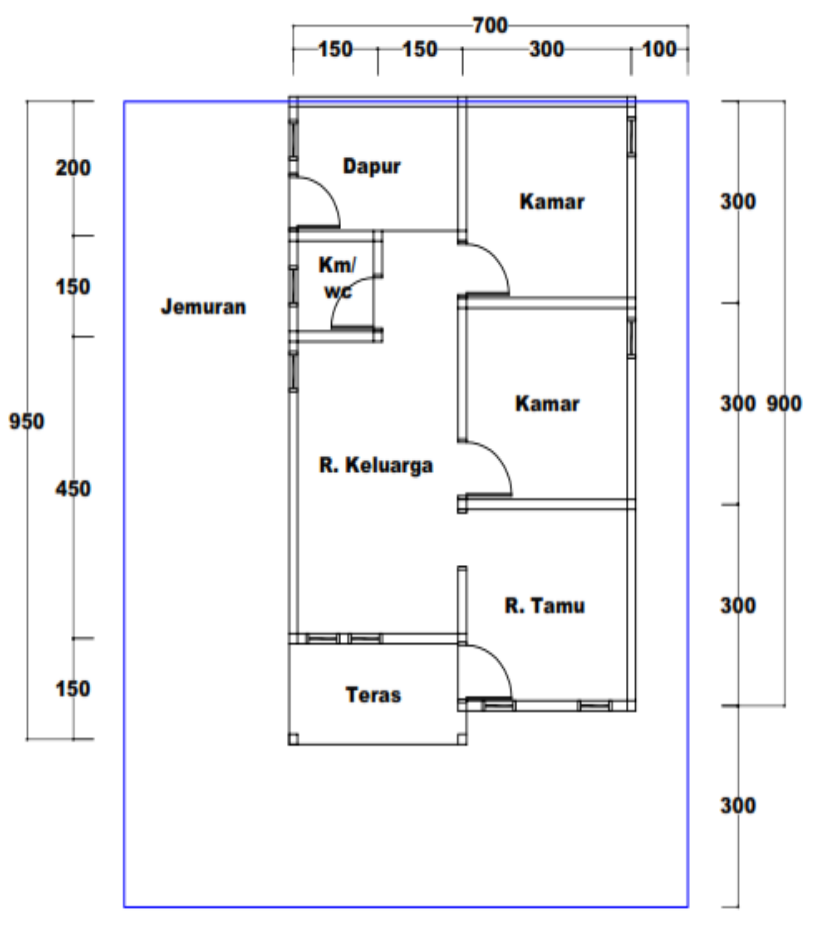

(b)

Gambar 4. Denah Rumah Tipe 36/120 (a) Eksisting dan (b) Setelah Renovasi 


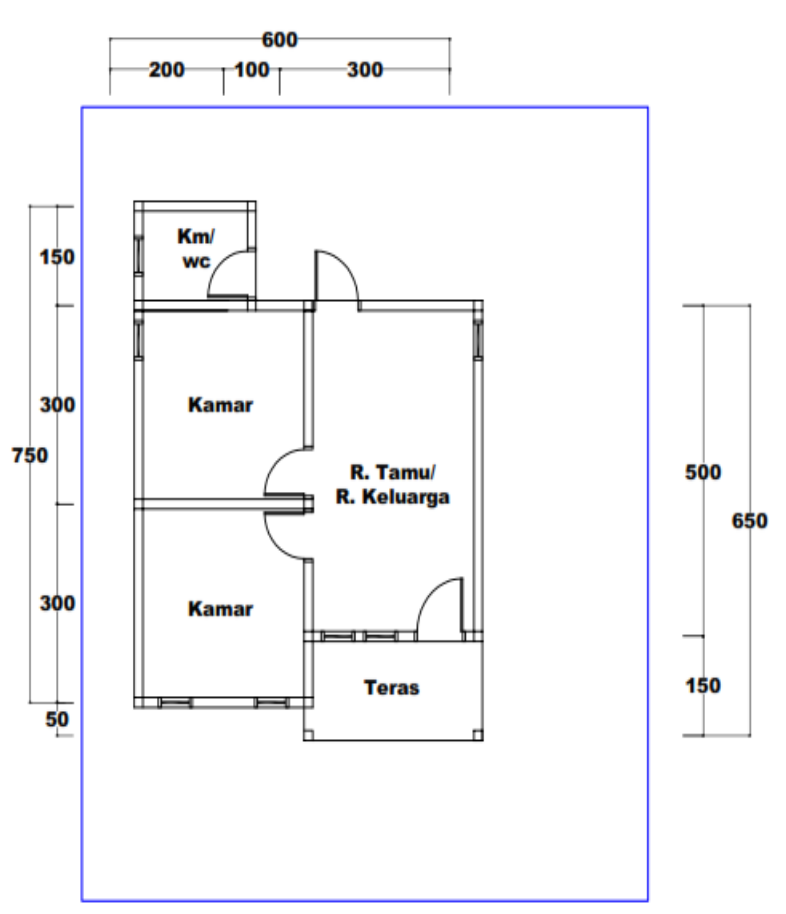

(a)

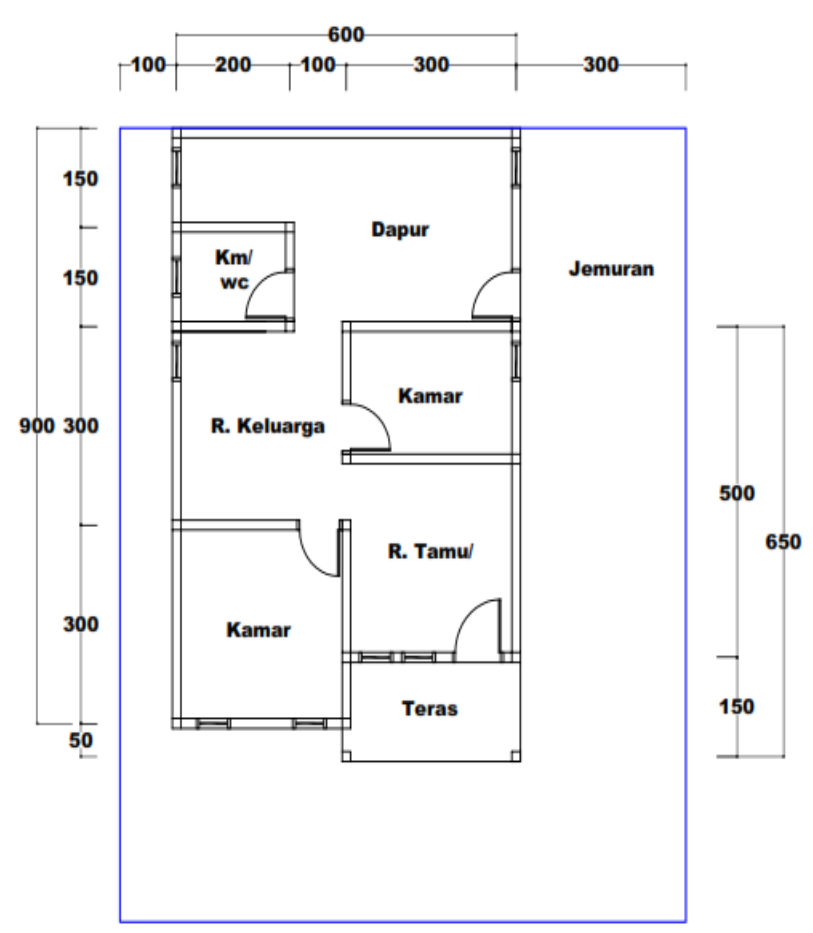

(b)

Gambar 5. Denah Rumah Tipe 36/120 (a) Eksisting dan (b) Setelah Renovasi

\section{KESIMPULAN}

Penelitian yang dilakukan pada 5 wilayah di Kecamatan Martapura untuk mendapatkan tujuan utama dari penelitian ini yaitu mengimplementasikan konsep rumah Islami pada perumahan di Martapura, telah menghasilkan beberapa kesimpulan sebagai berikut:

1. Masyarakat Martapura memahami akan rumah dengan konsep Islami. Namun tingkat pemahaman mereka hanya sampai pada hal-hal yang biasa berlaku di masyarakat saja. Seperti tidak boleh ada hiasan berupa patung, boneka besar, gambar manusia atau binatang di dalam rumah. Tidak ada pernak pernik yang menyerupai simbol agama selain islam, tidak memelihara anjing \& babi, memiliki musholla di dalam rumah, memiliki pajangan kaligrafi atau ulama-ulama besar, arah saat buang hajat (posisi kloset) yang tidak menghadap kiblat, \& penghuninya melaksanakan syariat Islam. Serta kamar anak laki-laki dan perempuan harus dipisah. Sementara untuk prinsip dasar dari rumah Islami yaitu menjaga privasi penghuninya dari pandangan umum yang diaplikasikan pada penataan ruang, hanya sebagian kecil saja yang benar-benar mengetahuinya;

2. Berdasarkan hasil penelitian diketahui bahwa penataan ruang rumah sederhana tipe $36 \mathrm{~m} 2$ atau $45 \mathrm{~m} 2$ pada komplek perumahan di Martapura sedikit kurang sesuai dengan konsep rumah Islami. Salah satu faktor penyebabnya adalah karena luasan rumah yang terbatas. Namun apabila penelitian dilakukan pada rumah dengan tipe lebih dari $45 \mathrm{~m} 2$, maka konsep rumah Islami akan lebih bisa diaplikasikan.

3. Contoh denah rumah sederhana tipe $36 \mathrm{~m} 2$ - $45 \mathrm{~m} 2$ yang berkonsep Islami seperti pada Gambar 1, Gambar 2 dan Gambar 3 sangat mudah dibuat dan diaplikasikan pada perumahan di Martapura;

4. Biaya yang diperlukan untuk membangun rumah sederhana tipe 36 dan 45 dengan konsep Islami tidak terlalu besar bedanya dengan biaya membangun rumah sederhana tipe 36 dan 45 yang umum di pasaran. Untuk tipe 36 dengan luas tanah $100 \mathrm{~m} 2-120 \mathrm{~m} 2$ selisih biayanya hanya sekitar Rp. 1,3 juta - Rp. 1,5 juta. Sedangkan untuk tipe 45 dengan luas tanah $140 \mathrm{~m} 2$ selisih biayanya hanya sekitar Rp. 1,8 juta. 


\section{DAFTAR RUJUKAN}

Ahmad, Fauzi. 2015. 8 Prinsip Desain Rumah Dengan Konsep Islam. http:/www.prodezign.web.id diakses 28 Nopember 2016.

Akdon, Sahlan. 2005. Aplikasi Statistik dan Metode Penelitian Untuk Adminsitrasi dan Managemen, Maret. Bandung: Dewa Rucchi

Arikunto. S. 2010. Prosedur Penelitian Suatu Pendekatan Praktik. Yogyakarta: Rineka Cipta.

Burhanuddin. 2010. Konsep Teritori dan Privasi Sebagai Landasan Perancangan Dalam Islam. Fakultas Teknik Jurusan Arsitektur Universitas Tadulako. 